\title{
NALAR IDEOLOGIS FIQIH DALAM TAFSIR AL-QUR'AN (Telaah Konstruksi Tafsir Pada Masa Abbasiyah)
}

\author{
Benny Afwadzi \\ UIN Maulana Malik Ibrahim Malang
}

\begin{abstract}
Abstrak
Artikel ini mengkaji tentang nalar ideologis fiqih yang muncul dalam periode dinasti Abbasiyah, yang mengkhususkan pada kitab tafsir dari ulama pengikut madzhab empat, yakni madzhab Hanafi, Māliki, Syāfi'i, dan Hanbali. Ulama Hanafiyah diwakili oleh alJashshāsh, ulama Mālikiyah diwakili oleh Ibnu al-'Arabi, ulama Syāfi'iyah diwakili oleh Fakhruddīn al-Rāzi, dan ulama Hanābilah diwakili oleh Ibnu al-Jauzi. Kesimpulan yang diperoleh adalah bahwa penafsiran terhadap ayat-ayat al-Qur'an dalam masingmasing kitab tafsir terlihat membela pemikiran dalam madzhab yang dianut oleh penulisnya. Beberapa sampel yang diambil, yakni diskursus 'àm dan khāsh, amr dan nahy, serta lafadz musytarak membuktikan bahwa masing-masing ulama madzhab mempertahankan ideologi yang terdapat dalam madzhabnya dalam bidang fiqih, sehingga tafsir hukum yang muncul berwarna dengan warna madzhab si mufassir.
\end{abstract}

Key Words: Abbasiyah, ideologis, fiqih, pembelaan madzhab.

\section{A. Pendahuluan}

Al-Qur'an sebagai manifestasi wahyu Tuhan pada umat manusia tidaklah dapat berbicara sendiri. Ia memerlukan manusia untuk dapat mengeksplorasi makna-makna terdalam yang dikandungnya. Dalam konteks ini, al-Qur'an didudukkan menjadi objek yang diinterpretasikan dan manusia sebagai subjek yang menginterpretasikan. Kedua entitas tersebut saling berdialektika satu dengan yang lainnya, sehingga terkadang suatu penafsiran larut dalam makna yang termaktub secara gamblang dalam teks al-Qur'an dan terkadang pula penafsiran hanyut dalam subjektivitas sang penafsir atau bahkan terjadi "perkawinan" antara makna teks al-Qur'an dan subjektivitas penafsir.

Dalam petikan sejarah peradaban Islam, ragam dan wujud penafsiran al-Qur'an selalu berkembang secara dinamis dalam setiap periode. Masing-masing periode mempunyai karakteristik dan episteme sendiri-sendiri, sehingga produk penafsiran menjadi sangat beragam. Merujuk pada pendapat Abdul Mustaqim, maka dapat dikatakan bahwa perkembangan epistemologi tafsir al-Qur'an dipetakan menjadi tiga bentuk, yaitu pertama, tafsir era formatif dengan nalar quasi-kritis yang terjadi pada masa klasik (dimulai sejak zaman Nabi sampai kurang lebih abad kedua hijriyah); kedua, tafsir era afirmatif dengan nalar 
ideologis yang muncul pada abad pertengahan; dan ketiga, tafsir era reformatif dengan nalar kritis yang berkembang pada masa modern-kontemporer. ${ }^{1}$

Saat ini memang pada hakikatnya masuk dalam kategori tafsir era reformatif yang dibumbuhi dengan nalar kritis, tetapi sebenarnya cukup urgen untuk menelisik konstruksi berpikir dalam wacana tafsir al-Qur'an pada era afirmatif. Hal ini dikarenakan ia menjadi semacam "jembatan penghubung" antara era formatif dengan era reformatif. Tanpa mengenal secara lebih jauh bentuk tafsir pada era afirmatif, maka tidak mungkin seseorang mampu memahami alasan mengapa tercipta epistemologi tafsir lanjutan pada era modernkontemporer. Untuk alasan itulah, kajian tafsir pada masa terkini tidak hanya diaktualisasikan dengan menyelami pemikiran tokoh-tokoh modern-kontemporer seperti Muhammad Abduh, Fazlurraḥman, Muḥammad Arkoun, Muḥammad Syahrur, Abid al-Jabiri, dan Fatimah Mernissi saja, tetapi kajian tafsir juga seyogyanya diarahkan untuk menelisik konstruksi pemikiran tafsir pada era afirmatif yang sarat dengan ideologi-ideologi madzhab. ${ }^{2}$

Masa Dinasti Abbasiyah merupakan salah satu representasi masa dari era afirmatif yang paling populer. Pada masa Abbasiyah ini, kajian fiqih atau yurisprudensi Islam menemukan format keemasannya, yang ditandai dengan berdiri kokohnya bangunan pemikiran masing-masing madzhab fiqih. Para pengikut imam-imam mujtahid masa-masa awal, seperti Abū Ḥanīfah, Mālik, al-Syāfi'i, dan Aḥmad bin Ḥanbal, mengelaborasi pandangan para pendahulunya dengan sedemikian rupa. Mereka menguatkan kaidah-kaidah pengambilan hukum (ushul fiqih) dan produk hukum Islam (fiqih) di madzhabnya dengan tafsir al-Qur'an dan terkadang pula menyerang madzhab lain. Dalam konteks ini, ideologi punya peranan besar dalam menentukan produk penafsiran.

\footnotetext{
${ }_{1}^{1}$ Abdul Mustaqim, Epistemologi Tafsir Kontemporer, (Yogyakarta: LkiS, 2010), 34-86.. Namun, dalam buku sebelumnya dengan judul Pergeseran Epistemologi Tafsir yang diterbitkan tahun 2008, Mustaqim terlihat tidak menyetujui penyematan 'nalar quasi-kritis' pada era formatif dan lebih memilih 'nalar mitis'. Menurutnya, secara subtansial tidak ada perbedaan antara istilah quasi kritis dengan mitis, sehingga ia lebih memilih istilah nalar mitis. Abdul Mustaqim, Pergeseran Epistemologi Tafsir, (Yogyakarta: Pustaka Pelajar, 2008), 34-35.

${ }^{2}$ Ideologi ini sangat berperan besar dalam pemikiran, dan terkadang dalam kasus-kasus tertentu mengakibatkan kerusuhan dan pertumpahan darah. Misalnya saja perseteruan yang diakibatkan oleh perbedaan penafsiran kata "maqām mahmūid" dalam QS. al-Isrā' ayat 79. Pengikut madzhab hanbali memaknainya dengan Allah mendudukkan Nabi bersama diri-Nya di arsy sebagai balasan atas tahajjudnya. Sementara itu, pihak lainnya yang dipengaruhi pemikiran Mu'tazilah memahami bahwa kata tersebut hendaknya tidak dimaknai sebagai tempat tertentu, tetapi sebuah tingkatan syafa'at yang Nabi Muhammad diangkat pada derajat tersebut sebab beliau melakukan shalat tahajjud. Kedua bentuk penafsiran ini semakin meluas menjadi dua kubu, sehingga terjadi kericuhan sampai saling membunuh dan akhirnya memaksa pihak militer turun untuk menghentikannya. Ignaz Goldziher, Madzhab Tafsir dari Klasik Hingga Modern, terj. M. Alaika Salamullah dkk., (Yogyakarta: elSAQ Press, 2006), 131.
} 
Melihat fenomena tersebut, dalam tulisan ini akan diulas mengenai konstruksi tafsir al-Qur'an pada masa dinasti Abbasiyah yang sarat dengan nalar ideologis. Nalar ideologis yang diuraikan adalah yang berkenaan dengan kajian fiqih dan ushul fiqih sebagai kajian yang paling diminati dalam tradisi Islam. Objek kajian sendiri difokuskan pada kerangka berpikir dan perdebatan yang muncul dalam bingkai madzhab empat serta kitab-kitab tafsir yang merupakan representasi dari pandangan-pandangan tersebut.

\section{B. Sejarah Kemunculan Dinasti Abbasiyah}

Peradaban Islam ditandai dengan dilahirkannya Nabi Muhammad pada abad ketujuh Masehi. Beliau hidup di kota kelahirannya, Makkah selama tiga belas tahun dan mencoba untuk merekonstruksi sistem teologi yang ada di masyarakat Makkah pada masa itu. Dalam hal ini, Nabi mengajak kepada suku Quraisy yang notabenenya merupakan penduduk kota Makkah agar kembali pada sistem teologi yang benar, yaitu monoteisme. Namun, dakwah Nabi di kota ini kurang begitu bisa diterima hingga akhirnya memaksa beliau hijrah dan bermukim di kota Madinah dan menetap di sana selama sepuluh tahun lamanya. Di Madinah inilah, Nabi mulai membangun pondasi kota ini sebagai sebuah negara.

Posisi Nabi ketika berada di Makkah dan Madinah pun berlainan. Pada saat berada di Makkah, Nabi lebih terkosentrasi sebagai pemuka agama, yang melakukan gerakan dakwah keislaman dan meneguhkan sistem teologi Islam. Di kota ini juga, Nabi memberikan edukasi kepada para pengikutnya terkait al-Qur'an dan tata cara praktiknya dalam kehidupan seharihari. Sementara itu di kota Madinah, Nabi lebih mempunyai posisi sebagai negarawan selain sebagai pemuka agama - yang membuat undang-undang bagi negara Islam dan syariat yang kemudian diikuti oleh orang-orang setelahnya serta terefleksikan dalam kehidupan mereka dalam aspek teologi, sosial, politik, dan juga ekonomi. ${ }^{3}$

Setelah Nabi wafat, tonggak pemerintahan digantikan oleh khalifah empat yang ideal, yaitu Abū Bakar, 'Umar bin Khaththāb, 'Utsmān bin `Affān, dan `Alī bin Abī Thālib. ${ }^{4}$ Pada era Abū Bakar, 'Umar bin Khaththāb, dan enam tahun awal pemerintahan 'Utsmān bin 'Affān, suhu politik Islam masih dalam keadaan yang cukup kondusif meskipun terjadi huru-

\footnotetext{
${ }^{3}$ Musāid Muslim Abdillāh Ali Ja'far, Atsar al-Tathawwur al-Fikrī fì al-Tafsīr fì al-Ashr al-Abbāsi, (Beirut: Muassasah al-Risālah, 1984), 20.

${ }^{4}$ Dikatakan ideal, sebab Abū Bakar bersifat bijaksana dan saleh, Umar bersifat berani dan adil, Usmān berperangai lembut dan agamis, serta Alī yang berwatak berani dan bersikap ilmiah. Akbar S. Ahmed, Citra Muslim: Tinjauan Sejarah dan Sosiologi, erj. Nunding Ram dan Ramli Yakub, (Jakarta: Erlangga, 1992), 39-40.
} 
hara oleh beberapa kalangan. Namun, pada saat enam tahun kedua, gonjang-ganjing politik mulai sangat terasa. Kondisi yang sangat tidak diharapkan ini pun menuai klimaksnya pada waktu pemerintahan 'Alī bin Ab̄̄ Thālib, yang banyak memunculkan konflik sesama umat Islam akibat perseteruannya dengan 'Āisyah dalam perang jamal dan juga perebutan kekuasaan antara dirinya dengan Mu āwiyah bin Abī Sufyān dalam perang shiffin.

Selanjutnya, kendali pemerintahan Islam dipegang oleh dinasti Umayyah dengan pendirinya Mu`āwiyah yang berhasil merebut kekuasaan dari 'Alī bin Abī Thālib dan meredam Ḥasan bin `Alī dengan cara damai. Dengan kemunculan dinasti ini, pemerintahan Islam yang sebelumnya didasarkan atas sistem demokrasi, diganti dengan sistem monarchiheridetis atau kerajaan secara turun temurun. Dalam sistem ini, pergantian pemimpin tidak dilakukan dengan cara pemilihan sebagaimana terjadi sebelumnya, akan tetapi dengan sistem keturunan. Dengan kata lain, yang berhak melanjutkan estafet kepemimpinan adalah keluarga dari si penguasa. Dinasti ini sendiri dimulai dengan Mu`āwiyah bin Abī Sufyān sebagai raja dan kemudian digantikan oleh anak keturunannya sampai sembilan puluh tahun lamanya. ${ }^{5}$

Di samping beberapa kemajuan dalam berbagai bidang, pada era dinasti Umayyah banyak terjadi konflik yang berujung pada runtuhnya dinasti ini. Montgomery Watt mencatat paling tidak ada empat faktor penghancur, yaitu pertama, ketidakpuasan sejumlah besar orang non-Arab yang memeluk Islam, terutama di Irak dan beberapa propinsi di Timur. Mereka disebut sebagai kaum mawāli dan diperlakukan secara inferior, yang dipandang sebagai golongan tingkat kedua; kedua, meningkatnya perpecahan diantara para kabilah Arab, yaitu antara Bani Qays (Arabia Utara) dan Bani Kalb (Arabia Selatan); ketiga, kekecewaan sejumlah besar orang yang prihatin akan keadaan keagamaan dinasti Umayyah yang melenceng dari nilai-nilai Islam; keempat, adanya perasaan keagaaman berupa kerinduan munculnya juru selamat atau ratu adil, yang beredar di kebanyakan propinsi dinasti Umayyah. Dengan sangat terampil, golongan Abbasiyah bisa menggalang perasaan itu untuk menggerakkan usaha militernya demi merebut kekuasaan dari Bani Umayyah. ${ }^{6}$

Usai hancurnya dinasti Umayyah, maka kekuasaan pun dilanjutkan oleh dinasti Abbasiyah, yang didirikan oleh Abū al-Abbās al-Saffāh bin Muhammad bin `Alī bin

\footnotetext{
${ }^{5}$ Badri Yatim, Sejarah Peradaban Islam, (Jakarta: Raja Grafindo Persada, 1995), 42.

${ }^{6}$ W. Montgomery Watt, Kejayaan Islam: Kajian Kritis dari Tokoh Orientalis, terj. Hartono Hadikusumo, (Yogyakarta: Tiara Wacana, 1990), 28-31.
} 
Nalar Ideologis Fiqih dalam Tafsir al-Qur'an .....

Benny Afwadzi

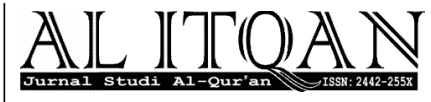

‘Abdullāh bin al-'Abbās (750-754 H.). Ia merupakan keturunan dari al-`Abbās, paman Nabi Muhammad. Meskipun demikian, menurut Hitti, tokoh yang patut dianggap sebagai pendiri sejati dinasti Abbasiyah adalah Abū Ja far al-Manshūr, pengganti Abū al-Abbās. Bagi Hitti, Abū Ja'far al-Manshūr merupakan khalifah terbesar dinasti Abbasiyah dan yang benar-benar membangun dinasti kedua Islam itu. Seluruh khalifah yang berjumlah tiga puluh lima (35) orang berasal dari garis keturunannya. Kekusaan dinasti ini berlangsung dalam rentang waktu yang sangat panjang, yaitu mulai dari tahun $132 \mathrm{H} / 750 \mathrm{M}$ sampai $656 \mathrm{H} / 1258 \mathrm{M}^{7}$

Puncak kejayaan dinasti Abbasiyah dicapai antara masa khalifah ketiga sampai khalifah kesembilan. Mereka adalah al-Mahdi (775-785 M.), al-Hādi (775-786 M.), Hārūn alRasyīd (786-809 M.), al-Ma'mūn (813-833 M.), al-Mu'tashim (833-842 M.), al-Watsiq (842847 M.), dan al-Mutawakkil (847-861 M.). ${ }^{8}$ Popularitas dinasti Abbasiyah sendiri mencapai puncaknya ketika Hārūn al-Rasyīd dan anaknya al-Ma'mūn bertahta. Pada masa dua khalifah hebat itulah dinasti Abbasiyah memiliki kesan baik dan menjadi dinasti paling terkenal dalam sejarah Islam. ${ }^{9}$

Beberapa kemajuan yang dapat dicapai pada era Khalifah Hārūn al-Rasyīd misalnya, mendirikan rumah sakit, lembaga pendidikan dokter, dan farmasi. Tercatat paling tidak ada 800 dokter dihasilkan pada masa ini. Di samping itu, pemandian-pemandian umum juga dibangun. Tingkat kemakmuran paling tinggi terwujud pada zaman khalifah ini. Kesejahteraan sosial, kesehatan, pendidikan, ilmu pengetahuan, kebudayaan, dan kesusastraan berada pada zaman keemasannya. Pada masa inilah negara Islam menempatkan dirinya sebagai negara terkuat dan tak tertandingi. ${ }^{10}$

Khalifah al-Ma'mūn, sebagai pengganti al-Rasyīd, dikenal sebagai khalifah yang sangat cinta ilmu. Pada masanya, penerjemahan buku-buku asing banyak digalakkan. Ia juga banyak mendirikan sekolah, salah satu karya besarnya yang terpenting adalah pembangunan Bait al-Hikmah, yakni pusat penerjemahan yang berfungsi sebagai perguruan tinggi dengan perpustakaan yang besar. Pada saat al-

\footnotetext{
${ }^{7}$ Philip K. Hitti, Hisory of The Arab, terj. Cecep Lukman Yasin dan Dedi Slamet Riyadi, (Jakarta: Serambi Ilmu Semesta, 2010), 360.

${ }^{8}$ Badri Yatim, Sejarah Peradaban Islam, 52.

${ }^{9}$ Philip K. Hitti, Hisory of The Arab, 369.

${ }^{10}$ Badri Yatim, Sejarah Peradaban Islam, 52.
} 
Ma'mūn berkuasa inilah, Baghdad sebagai pusat pemerintahannya menjadi pusat kebudayaan dan ilmu pengetahuan. ${ }^{11}$

Sebagai bentuk pemerintahan, tentunya tidak hanya mengalami pencapaianpencapaian cemerlang saja, tetapi kemunduran-kemunduran yang berimplikasi pada hancurnya dinasti ini pun terjadi. Kemerosotan-kemerosotan dinasti Abbasiyah disebabkan oleh faktor internal dan eksternal. Faktor internal terdiri atas persaingan antar bangsa, kemerosotan ekonomi, dan konflik keagamaan. Sementara itu, faktor eksternal yang timbul adalah adanya perang Salib dan serangan bangsa Mongol yang memporak-porandakan kekuasaan Abbasiyah. ${ }^{12}$ Akhirnya, pada masa khalifah ke-38, yakni al-Mu'tashim, dinasti ini pun mengalami kehancuran di tangan bangsa Mongol pada $1258 .{ }^{13}$

\section{Sejarah Fiqih dari Masa Nabi sampai Dinasti Abbasiyah}

Proses penurunan al-Qur'an yang memakan waktu 23 tahun terbagi menjadi dua periode, yakni periode Makkah dan Madinah. Masing-masing periode mempunyai karakteristik yang berbeda-beda. Pada periode pertama di Makkah, Materi al-Qur'an banyak memuat pondasi-pondasi teologis yang menekankan prinsip monoteisme dan penyerahan diri kepada Allah. Pada era ini, ayat-ayat hukum yang diturunkan sangat sedikit sekali. ${ }^{14}$ Hal ini terjadi sebab pada masa ini belum terbentuk komunitas muslim, yang dapat membuat aturan hukum Islam. Dengan kata lain, orang Islam pada periode ini hidup dalam komunitas orangorang musyrik, sehingga orang Islam tidak mampu untuk membuat legislasi tertentu dalam komunitas musyrik tersebut. ${ }^{15}$

Namun ketika Nabi hijrah ke Madinah, ayat-ayat hukum pun berangsur-angsur mulai diturunkan. Beberapa ayat yang berkenaan dengan hukum mulai menemui format yang formal. Dalam konteks ini, Islam pun pada akhirnya bisa menyempurnakan hukum-hukumnya serta akidah yang benar. Dalam tatanan historisnya, Nabi tidak meninggal sebelum terbentuk

\footnotetext{
11 Ibid., 53.

12 Ibid., 80-85.

${ }^{13}$ Philip K. Hitti, Hisory of The Arab, 370.

${ }^{14}$ Misalnya surat al-An'ām yang terdapat beberapa aspek hukum seperi haram makan binaang yang disembelih tidak dengan nama Allah dan keterangan tentang hewan-hewan yang haram dimakan (ayat 145). Keterangan ini terkait dengan masalah-masalah akidah, seperti orang orang Jahiliyah yang menyembelih binatang atas nama Tuhan mereka yang batil, mengharamkan dan menghalalkan sesuai dengan hawa nafsu mereka. Mun'im A. Sirry, Sejarah Fiqih Islam: Sebuah Pengantar, (Surabaya: Risalah Gusti, 1995), 23.
}

${ }^{15}$ Musūid Muslim Abdillāh Ali Ja'far, Atsar al-Tathawwur al-Fikri,136-137. 
Nalar Ideologis Fiqih dalam Tafsir al-Qur'an .....

Benny Afwadzi

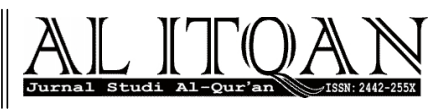

komunitas muslim yang sempurna. Problem pemahaman hukum pada era Nabi dikembalikan seutuhnya pada beliau, sehingga solusi atas masalah-masalah hukum bisa teratasi. Pasca meninggalnya Nabi, aplikasi al-Qur'an dan sunnah dilanjutkan oleh generasi penerusnya, yakni para sahabat dan tabi'in dengan pemahaman yang berbeda-beda antara satu dengan lainnya. $^{16}$

Ketika daerah kekuasaan Islam semakin luas, maka para sahabat menyebar ke berbagai macam daerah, baik di daerah yang berhasil ditaklukkan maupun daerah yang hendak dimasuki dakwah Islam. Maka, ketika para sahabat tersebut menetap di sebuah daerah, lantas masyarakat setempat meminta fatwa hukum pada sahabat berdasarkan alQur'an, Sunnah, atau hasil ijtihad mereka sendiri. Selain itu, para sahabat ini juga mempunyai murid-murid yang diajarkan langsung mengenai hukum Islam. Akhirnya, komunitas ini melembaga dan menjadi madrasah dalam suatu wilayah. ${ }^{17}$

Di Irak misalnya, ada sahabat `Abdullāh bin Mas`ūd, Ḥudzaifah bin al-Yamān, `Imrān bin Hushain. Di wilayah inilah, Khalifah `Ali bin Abī Thālib menjadikannya sebagai pusat pemerintahan. Madrasah ini melahirkan Abū Ḥanīfah al-Nu'mān bin Tsābit (w. 150 H.), yang kemudian dinamakan sebagai madrasah al-ra'yi atau Madrasah Irak. Di Syam tinggal Abū 'Ubaidah Amir bin al-Jarrāḥ, Khālid bin al-Walīd, Mu'āwiyah bin Abī Sufyān, Yaz̄̄d bin Abī Sufyān, Muādz bin Jabal, Syarḥabīl bin Ḥasanah, Abū al-Dardā', dan Bilāl bin Rabāḥ. Daerah ini kemudian dijadikan dinasti Umayyah sebagai ibukota pemerintahannya. Dari wilayah ini menghasilkan Abū `Amr al-Auzā'i (w. 157 H.) sebagai ahli fiqih terkenal. Para sahabat yang tinggal di Mesir seperti Abū Dzar al-Ghifāri, Zubair bin al-Awwām, Sa'ad bin Abī Waqāsh, Amr bin al-Ash yang kemudian pindah ke Syam, dan `Abdullāh bin `Amr bin al-Ash. Produk faqīh yang dihasilkan dari madrasah Mesir ialah al-Laits bin Sa'ad (w. 157 H.). ${ }^{18}$

Adapun yang tinggal di Madinah ialah Abū Bakar, 'Umar bin Khaththāb, 'Utsmān bin 'Affān, 'Ali bin Abī Thālib, 'Abdullāh bin 'Umar, dan 'Āisyah. Di kota inilah pemikiranpemikiran mereka dijadikan referensi oleh para fuqaha' hingga terbentuknya madzhab. Sementara itu, di Makkah ada `Abdullāh bin 'Abbās dan Zayd bin Tsābit. Para sahabat tersebut itulah yang membangun pondasi fiqih di Hijāz dan berhasil mencetak seorang

\footnotetext{
16 Ibid., 137.

17 Ibid., 150.

18 Ibid., 150-154.
} 
bintang besar dalam ilmu fiqih, yaitu Mālik bin Anas. Madrasah ini disebut Madrasah Hijāz atau madrasah ahli hadits. ${ }^{19}$

Pada awalnya, para ahli fiqih di sebuah madzhab mengambil pendapat yang dikembangkan dalam madzhab lain tanpa disertai beban. Namun, hal ini pun memudar dan musnah tatkala fanatisme bermadzhab mulai muncul. Semua hasil kajian hanya diambil dari dari madzhabnya sendiri, bahkan timbul keyakinan bahwa pemahaman yang ada pada madzhab lain adalah tidak benar. Hal seperti ini tidak ditemukan dalam dalam bingkai pemikiran mujtahid muthlaq yang bermunculan pada masa-masa awal, seperti Abū Ḥan̄ifah, Mālik, al-Laits, al-Auzā’i, al-Syāfìi, dan Aḥmad bin Hanbal. ${ }^{20}$ Dalam konteks fanatisme madzhab inilah ideologi yang dianut bermain dalam wilayah kajian fiqih.

Sebenarnya, munculnya perbedaan pemikiran dan metodologi di antara masingmasing madrasah disebabkan adanya perbedaan pikiran manusia itu sendiri, yang dipengaruhi oleh perbedaan kepribadian, rasionalitas, dan sosio-kultural. Hal yang menjadi penyebab utama yang melandasi timbulnya perbedaan adalah adanya perbedaan sahabat yang berdiam di suatu wilayah. Mereka masing-masing memiliki rasionalitas dan metode berijtihad sendirisendiri dalam menggali hukum syariat, yang kemudian diajarkan pada generasi tabi in dan begitu seterusnya. Selain itu, perbedaan ketersediaan hadits Nabi dan kondisi lingkungan menjadi aspek penting juga yang menentukan perbedaan tersebut. ${ }^{21}$

Pada era selanjutnya, kodifikasi menjadi hal penting yang harus dilakukan, sebab pemikiran yang muncul tanpa dituangkan dalam wujud tulisan tidak akan bisa dikenal dan dikenang orang lain. Konon, Muḥammad bin al-Ḥasan dan Abū Yūsuf pernah menulis kajian tentang ushul fiqih, akan tetapi hasil karyanya tidak sampai ke tangan kita. Adapun kitabkitab awal yang berhasil sampai pada kita sekarang ini, misalnya kitab al-Risālah dan alUmm karya Muḥammad bin Idrīs al-Syāfi 'i, al-Muwaththa' hasil karya Mālik bin Anas, dan al-Kharrāj hasil tulisan salah satu murid Abū Ḥanīfah, yaitu Abū Yūsuf. ${ }^{22}$

Ada tiga metode dalam penulisan fiqih pada era Abbasiyah, yaitu pertama, fiqih bercampur dengan hadits dan fatwa sahabat serta tabi'in, misalnya al-Muwaththa' karya

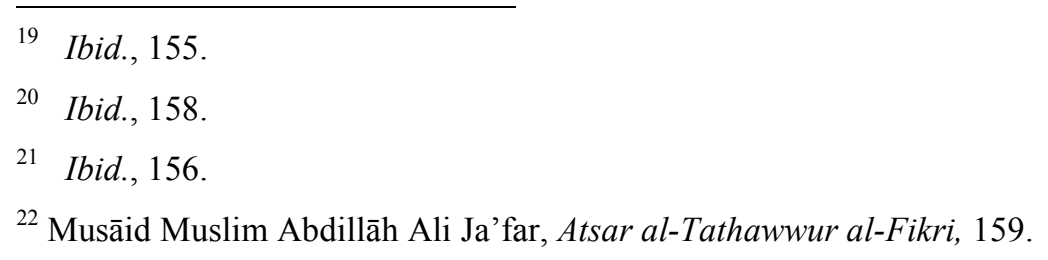


Nalar Ideologis Fiqih dalam Tafsir al-Qur'an .....

Benny Afwadzi

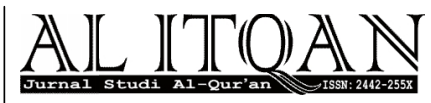

Imam Mālik, al-Jāmi al-Kabīr karya Sufyān al-Tsauri, dan Ikhtilāf al-Hadīts hasil goresan tinta Imam al-Syāfi i. Kedua, fiqih yang ditulis secara terpisah dari hadits dan atsar. Metode ini banyak dipergunakan oleh fuqahā' Hanafiyah, seperti Abū Yūsuf dalam al-Kharrāj dan Zhahīr al-Riwāyah al-Sittah karya Muhammad bin Hasan. Selain itu, ada pula karya besar dalam madzhab Māliki yang menggunakan metode ini, yakni al-Mudawwanah, hasil dialog dan tanya jawab antara Mālik dan salah satu muridnya, Ibnu Qāsim. Ketiga, penulisan komparatif fiqih, seperti al-Umm karya Imam al-Syāfi ‘ i. ${ }^{23}$

Secara periodik, menurut penuturan Musāid, pada sejarawan membagi sejarah fiqih menjadi empat periode. ${ }^{24}$ Periode Pertama dimulai dari pengutusan Nabi sampai meninggalnya beliau. Pada masa ini, Nabi menjelaskan langsung ayatayat al-Qur'an, baik yang berhubungan dengan syariat, teologi, kisah-kisah, maupun hal lain sebagainya. ${ }^{25}$ Periode kedua dimulai ketika Abū Bakar didaulat menjadi khalifah sampai akhir pemerintahan Khulafaur Rasyidin. Sumber hukum yang digunakan pada era ini adalah al-Qur'an, sunnah, konsensus sahabat, dan qiyas atau ijtihad. Contoh yang dapat diketengahkan misalnya Abū Bakar yang menyelesaikan problem kalālah dengan rasionya dan kompilasi al-Qur'an atas usulan 'Umar bin Khaththāb. Periode ketiga ditandai dengan munculnya dinasti Umayyah sampai hancurnya dinasti ini. Masa ini disebut juga dengan masa shighār al-shaḥābah dan kibār al-tābi'īn. Referensi hukum yang dipakai adalah al-Qur'an, sunnah, konsensus, dan qiyas. Pada era ini terbentuk madrasah-madrasah di masing-masing daerah. $^{26}$ Periode keempat adalah masa dinasti Abbasiyah yang merupakan era keemasan dari fiqih. Pada masa ini berbagai macam metodologi berkembang dalam menganalisis hukum yang ada dalam al-Qur'an dan sunnah. ${ }^{27}$

\footnotetext{
${ }^{23}$ Mun'im A. Sirry, Sejarah Fiqih Islam, 74-75.

${ }^{24}$ Lihat Musāid Muslim Abdillāh Ali Ja'far, Atsar al-Tathawwur al-Fikri, 138-145

${ }^{25}$ Ini merupakan kondisi umum pada masa Nabi, tetapi juga ada kasus partikular dengan ditandai pemberian wewenang Nabi pada Muadz bin Jabal untuk berijtihad ketika hendak pergi ke Yaman.

${ }^{26}$ Perlu diketahui bahwa ketika khulafaur Rāsyidīn menaklukan suatu wilayah, maka mereka pun mengutus seorang Amir dan disertai dengan dua orang ahli agama atau lebih yang bertugas untuk mejadi hakim di suatu wilayah tersebut. Maka dari sinilah kemudian menjadi embrio dan pada era selanjutnya memunculkan madrasah di suatu wilayah.

${ }^{27}$ Mun'im A. Sirry secara lebih luas dan kritis membagi periodesasi fiqih terbagi menjadi enam periode, yaitu fiqih di era kenabian, era khalifah empat, era shighār Sahabat dan Tabi'̄̄n, era keemasan, era keterpakuan tekstual, dan era kebangkitan kembali. Lihat Mun'im A. Sirry, Sejarah Fiqih Islam: Sebuah Pengantar, (Surabaya: Risalah Gusti, 1995).
} 


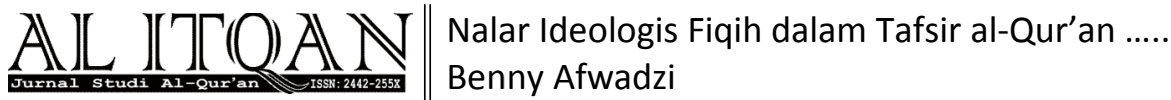

\section{Madzhab Empat dalam Kajian Fiqih dan Kitab Tafsirnya}

\section{Madzhab Hanafi}

Pendiri Madzhab ini adalah al-Nu'mān bin Tsābit bin Zuhthi atau yang akrab dipanggil Abū Ḥan̄̄ah. Dia lahir di Kufah pada tahun 80 H. dan wafat tahun 150 H. Sebagian besar riwayat menyebutkan bahwa ia berasal dari keturunan Persia dan bukan orang Arab. ${ }^{28}$ Abū Ḥanīfah dikenal sebagai seorang rasionalis di bidang fiqih sebab banyak berpegang pada akal, sehingga madrasahnya disebut sebagai madrasah ahli ra'yi. Ia juga dikenal sebagai orang yang bijaksana dan tidak haus akan kekuasaan. Penampilannya rapi dan gagah dan berusaha tampil sebagaimana sosok Rasulullah; berjenggot rapi, berpakaian rapi, memakai sorban atau berkopiah, dan juga menggunakan wangi-wangian. ${ }^{29}$

Madzhab fiqih yang pertama kali muncul dan berlanjut hingga masa sekarang adalah madzhab ini. Pada awalnya, 'Abdullāh bin Mas'ūd menetap di Kufah setelah diutus oleh khalifah 'Umar bin Khaththāb untuk menjelaskan permasalahan-permasalahan agama Islam pada masyarakat Kufah. Setelah ia meninggal, khalifah `Ali bin Abī Thālib datang dan menjadikan kota ini sebagai pusat pemerintahannya. ${ }^{30}$ Para tabi īn di kota ini pun menimba fiqih dari mereka berdua, misalnya Suraih bin Haris al-Kindi, 'Alqamah bin Qays al-Nakhai, Masrūq bin al-Ajda' al-Hamdāni, dan al-Aswab bin Yazīd al-Nakhai. Generasi setelahnya pun mempelajari fiqih dari tokoh-tokoh tersebut. Tokoh yang paling penting dari mereka seperti Ibrāhīm al-Nakhai, dan Amir bin Syarāḥ̄l al-Sya bi. Kemudian, Hammād bin Abī Sulaimān mengkaji fiqih dari dua tokoh populer tersebut. Ḥammād inilah yang menjadi guru dari Abū Hanīfah, sang pendiri madzhab Hanafi yang rasionalis. ${ }^{31}$

Adapun metode yang diusung oleh Abū Hanīfah tercermin sebagaimana yang dituturkannya:

"Saya menggali hukum dengan kitab Allah. Apabila tidak ditemukan di dalamnya, maka saya akan menggalinya dari sunnah Rasul. Jika tidak ditemukan juga dalam kitab Allah dan Sunnah Rasul, maka saya akan mencarinya dalam perkataan sahabat-sahabat Nabi. Dalam hal ini, saya akan mengambil dari sahabat yang saya kehendaki dan akan meninggalkan sahabat yang saya kehendaki pula. Dan saya tidak mengeluarkan perkataan mereka kepada

\footnotetext{
28 Ibid., 82.

${ }^{29}$ Imam Pamungkas dan Maman Surahman, Fiqih 4 Madzhab, (Jakarta: al-Makmur, 2015), 19.

${ }^{30}$ Musāid Muslim Abdillāh Ali Ja'far, Atsar al-Tathawwur al-Fikri, 168.

31 Ibid., 168
} 
Nalar Ideologis Fiqih dalam Tafsir al-Qur'an .....

Benny Afwadzi

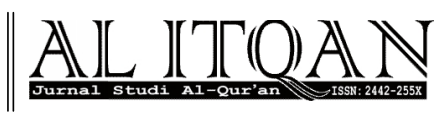

perkataan yang lain. Maka, apabila suatu perkara sudah selesai pada Ibrāhīm alNakhai, al-Sya'bi, Ibnu Sīrīn, al-Hasan, Athā', Saīd bin al-Musayyab, maka suatu kaum harus berijtihad sebagaimana mereka berijtihad",32

Itulah yang menjadi pokok metode istinbath hukum Abū Ḥanīfah. Namun, apabila tidak ditemukan juga dalam urutan proses pengambilan hukum sebagaimana dipaparkan di atas, maka ia akan berijtihad. Secara singkat, metode yang diusung oleh Abū Ḥanīfah terdiri atas al-Qur'an, Sunnah, perkataan sahabat, konsensus, qiyas, istihsān, dan urf (adat). Para murid Abū Ḥanīfah pun mengambil metode pokok tersebut, tetapi terkadang hasil yang didapatkan oleh mereka berbeda dengan hasil pemikiran Abū Hanīfah. ${ }^{33}$

Diantara kitab tafsir yang bercorak Hanafiyah adalah Ahkām al-Qur'ān karya Abū Bakar Aḥmad bin Ali al-Rāzi (305-370 H.) atau yang terkenal dengan julukan "alJashshāsh." ${ }^{34}$ Ia merupakan sarjana yang tinggal di Baghdad, dan menjadi guru bagi para ahli fiqih yang ada di sana. Selain berkompeten dalam bidang ilmu fiqih, sarjana yang menimba ilmu pada Abū al-Hasan al-Karkhi ini juga seorang yang wira'i dan tidak tergila-gila pada dunia. Khatīb al-Baghdadi pernah berkata terkait sosok pribadinya: "Ia merupakan imam bagi pengikut Abū Ḥanīfah (Hanafiyah) pada masanya dan terkenal dengan kezuhudannya.” Beberapa kitab yang dikarang oleh Abū Bakar al-Jashshāsh seperti Aḥkām al-Qur'ān, Syarah Mukhtashar Abū Ḥasan al-Karkhi, Syarah Mukhtashar al-Thahāwi, dan Syarah al-Jāmi' Muhammad bin Hasan. ${ }^{35}$

Kitab Ahkām al-Qur'an ini berjumlah lima jilid (taḥqīq Muhammad Shādiq Qamhāwi). ${ }^{36}$ Kitab ini sendiri merupakan produk konkrit dalam tafsir bercorak fiqih madzhab. Hanya saja, kitab yang ditulis oleh pengikut madzhab Hanafi yang fanatik ini sebenarnya tidak seperti kitab tafsir pada umumnya melainkan lebih mirip dengan kitab fiqih dengan sistematika bab tertentu, meskipun pembahasanya diurutkan sesuai tartib mushafi. Ia tidak memaparkan tafsir seluruh ayat al-Qur'an, akan tetapi hanya menuliskan ayat-ayat yang menjadi dasar hukum, atau yang menjadi pendukung pendapat dalam madzhab Hanafi, atau

\footnotetext{
32 Ibid., 172.

33 Ibid., 173.

${ }^{34}$ Al-Jashshāsh secara bahasa merupakan orang yang mempunyai pekerjaan untuk memplester dan memutihkan dinding. Mirip seperti tukang cat dalam konteks pekerjaan sekarang.

35 Muḥyiddīn Abī Muḥammad Abd al-Qādīr al-Qurasyi al-Ḥanafi, al-Jawāhir al-Mudhiyyah fì Thabaqāt alHanafiyyah, (Saudi Arabia: Hijr li al-Tibā'ah wa al-Nasyr wa al-Tauzi' wa al-I'lān, 1993), juz I, 220-224.

${ }^{36}$ Abū Bakar Aḥmad bin Ali al-Rāzi al-Jashshāsh, Aḥkām al-Qur'ān, (Beirut: Dār al-Iḥyā' al-Turās al-'Arabi, 1992).
} 
juga ayat yang menjadi dalil penolak pendapat di luar madzhabnya. Dalam kitabnya, Abū Bakar al-Jashshāsh menyajikan tafsir ayat-ayat al-Qur'an dengan judul tertentu tentang sebuah permasalahan dalam fiqih, yang kemudian diuraikan mengenai hukum-hukum yang terkandung di dalamnya. ${ }^{37}$

\section{Madzhab Mālikī}

Pendiri madzhab ini adalah Mālik bin Anas bin Mālik bin `Āmir al-Asbahī. Ia lahir pada tahun $93 \mathrm{H}$. di Madinah dan meninggal pada $179 \mathrm{H}$. Mālik adalah keturunan ArabYaman. Sebagian besar hidup Mālik bin Anas dihabiskan di Madinah dan sepanjang riwayat yang ada dia tidak pernah meninggalkan kota itu. ${ }^{38}$ Madrasah Mālik bin Anas di Madinah disebut sebagai madrasah ahli hadits, sebab lebih banyak menggunakan hadits-hadits sebagai sumber hukum Islam. Madinah sendiri merupakan tempat melimpah ruahnya hadits. Selain itu, ia juga mengambil perilaku orang-orang Madinah ('amal ahli al-Madīnah) sebagai sumber hukum dengan menganggapnya seperti hadits mutawātir.

Madinah merupakan kota yang ditinggali oleh Nabi, dan sepeninggal Nabi pun banyak sahabat yang masih tetap berdomisili di sini, misalnya 'Umar bin Khaththāb, 'Abdullāh bin 'Umar, 'Āisyah, Zayd bin Tsābit, dan `Abdullāh bin `Abbās di Makkah. Setelah itu, banyak tabi in yang belajar pada mereka, sehingga beberapa dari mereka dikenal sebagai tujuh atau delapan fuqah̄̄` kota Madinah. Mereka adalah 'Ubaidillāh bin `Abdullāh bin 'Utbah, 'Urwah bin al-Zubair, al-Qāsim bin Muḥammad bin Abū Bakar, Sa `̄id bin al-Musayyab, Sulaimān bin Yasār, Khārijah bin Zayd bin Tsābit, Sālim bin `Abdullāh bin 'Umar, dan Abū Bakar bin `Abdurraḥmān al-Haris. ${ }^{39}$ Fiqih fuqahā’ besar Madinah tersebut lantas dipelajari oleh generasi setelahnya. Tokoh populer yang belajar langsung pada mereka adalah Ibnu Syihāb al-Zuhrī, Nāfi', Abū al-Zinād ‘Abdullāh bin Zakwān, Rabī’ah al-Ra'ȳ̄, dan Yaḥyā bin Sa`ōd. Namanama tersebut merupakan guru dari Mālik bin Anas. ${ }^{40}$

Adapun metode yang dijalankan Mālik bin Anas dalam menggali hukum Islam adalah al-Qur'an, sunnah, kemudian hadits mursal dengan cukup intensif selama tidak bertentangan dengan tradisi ahli Madinah. Pada umumnya, para pengikut Imam Mālik (Mālikiyah)

\footnotetext{
${ }^{37}$ Musāid Muslim Abdillāh Ali Ja'far, Atsar al-Tathawwur al-Fikrī, 174-177.

${ }^{38}$ Mun'im A. Sirry, Sejarah Fiqih Islam, 92.

${ }^{39}$ Musāid Muslim Abdillāh Ali Ja'far, Atsar al-Tathawwur al-Fikrī, 180-181.

${ }^{40} \quad$ Ibid., 182.
} 
Nalar Ideologis Fiqih dalam Tafsir al-Qur'an .....

Benny Afwadzi

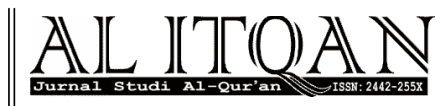

berhujjah dengan riwayat dari Mālik, yang berasal dari tradisi penduduk Madinah pada masanya. Sementara itu, sumber hukum yang dipegang Mālikiyah adalah al-Qur'an, sunnah, konsensus, tradisi ahli Madinah, qiyas, istihsān, istishāa, al-mashālih al-Mursalah, syad alDzarāi ${ }^{\prime}$ dan adat kebiasaan. ${ }^{41}$

Kitab tafsir bercorak fiqih yang dikarang oleh salah satu ulama Mālikiyah adalah Aḥkām al-Qur'ān karya Abū Bakar Muḥammad bin `Abdillāh bin Muḥammad (468-543 H.) atau yang dikenal dengan nama Ibnu al-Arabī. ${ }^{42}$ Ia merupakan pengikut madzhab Mālikī di Andalusia (Spanyol), yang menempati tingkatan (thabaqāh) kesebelas di kalangan ulamaulama Mālikiyah. Ibnu al-'Arabī merupakan sarjana yang produktif dengan menulis banyak sekali kitab dalam berbagai disiplin ilmu, yakni tafsir, hadits, fiqih, sejarah, dan ushul fiqih. Hal ini menunjukkan bahwa Ibnu al-'Arabī termasuk sarjana yang mampu menggeluti berbagai macam disiplin ilmu yang berbeda-beda. Dalam bidang kajian studi al-Qur'an, guru dari Qādhī `Iyādh ini mengarang beberapa kitab, seperti Aḥkām al-Qur 'ān, Musykīl al-Kitāb wa al-Sunnah, al-Nāsikh wa al-Mansūkh, dan Qānūn al-Ta 'wīl. ${ }^{43}$

Kitab tafsir madzhab yang berjumlah lengkap empat jilid ini (taḥqīq Muḥammad Abd al-Qādir `Athā) ${ }^{44}$ menjelaskan ayat-ayat al-Qur'an dan hukum-hukumnya dengan perspektif madzhab Mālikī. Namun, sarjana yang cukup fanatik pada madzhabnya ini juga terkadang memaparkan pendapat madzhab lain selain yang dianut dalam madzhab Mālikī. Meskipun demikian, pencantuman yang dilakukannya hanya sebatas sebagai bentuk komparasi dan penolakan saja. Ia tetap mengunggulkan pendapat yang terdapat di kalangan Mālikiyah. Dalam kitab tafsirnya, Ibnu al-'Arabī tidak menafsirkan ayat-ayat al-Qur'an secara keseluruhan, tetapi hanya ayat-ayat yang mempunyai kandungan hukum saja dengan memakai sistematika sesuai urutan mushaf. Ketika menafsirkan, ia mengeksplorasi aspek kebahasaan, mencantumkan asbāb al-nuzūl jika ditemukan, hadits-hadits yang berkaitan, dan penjelasan kandungan hukum yang dimiliki oleh ayat yang ditafsirkan secara global. ${ }^{45}$

\footnotetext{
41 Ibid., 185.

${ }^{42}$ Ibnu al-'Arabī berbeda dengan Ibnu 'Arabī. Jika nama pertama merupakan ahli fíqih di kalangan Malikiyah yang menjadi objek kajian dalam tulisan ini, akan tetapi nama yang kedua adalah tokoh sufi yang terkenal dengan wahdatul wujudya.

${ }^{43}$ Muḥammad bin Muḥammad bin 'Umar bin Qāsim Makhlūf, Syajarah al-Nūr al-Zakiyyah fì Thabaqāt alMālikiyyah, (Beirut: Dār Kutub al-Ilmiyyah, 2003), juz I, 199-201.

${ }^{44}$ Abū Bakar Muḥammad bin 'Abdillāh Ibn al-'Arabī, Ahkām al-Qur'ān, (Beirut: Dār Kutub al-Ilmiyyah, 2003).

${ }^{45}$ Musāid Muslim Abdillāh Ali Ja'far, Atsar al-Tathawwur al-Fikrī, 186-189.
} 


\section{Madzhab Syāfì i}

Imam madzhab ini adalah Muḥammad bin Idrīs al-Syāfi i, yang dilahirkan pada 150 H. dan wafat di Mesir pada 204 H. Sebagian besar riwayat menyebutkan bahwa ia lahir di Ghazza Palestina dari keturunan Quraisy dan nasabnya bertemu dengan Nabi pada kakeknya, Abdi Manaf. ${ }^{46}$ Madzhab al-Syāfìi merupakan aliran moderat dalam bidang fiqih, yang mensintesiskan kubu ahli hadits di Madinah dan ahli ra yī di Irak. Ia merupakan ulama yang menimba ilmu secara langsung pada dua kubu yang kontradiksi tersebut, di madrasah ahli hadits dan juga ahli ra'yi.

Awalnya, Imam al-Syāfi i sangat cenderung pada madzhab Māliki, sebab ia hidup bersama Imam Mālik selama tiga tahun. Imam al-Syāfi ’ i belajar secara intens dengan gurunya tersebut, yang mengantarkan dirinya memiliki pikiran layaknya madrasah ahli hadits. Namun setelah ia mengembara ke Baghdad dan Irak yang merupakan basis madrasah ahli ra yi serta menetap di sana untuk beberapa tahun lamanya dan mempelajari fiqih Abū Hanīfah dan pemikiran rasional ahli ra'yi, maka kemudian timbul sisi moderatisme al-Syāfi $\overline{1}$ yang mengkompromikan antara kedua kubu madrasah tersebut. ${ }^{47}$

Adapun metode penggalian hukum Islam Imam al-Syāfìi tercantum dalam magnum opusnya al-Risālah. Sementara kalangan Syafî̀iyyah mengambil hukum dari al-Qur'an, sunnah, baik yang berstatus aḥād shahị maupun yang mutawātir, konsensus yang terjadi di suatu masa orang Islam, pendapat sahabat yang tidak terjadi pertentangan di dalamnya, memilih salah satu pendapat sahabat yang paling mendekati al-Qur'an dan sunnah, dan yang terakhir adalah qiyas yang merupakan ciri khas dalam madzhab Syāfi ${ }^{1}{ }^{48}$

Di antara kalangan Syafî̀iyyah yang terkenal adalah Muhammad bin 'Umar bin alḤasan bin al-Ḥusain al-Taimī al-Bakrī (544-606 H.) atau yang populer dengan nama Fakhruddīn al-Rāzī, pengarang kitab tafsir Mafātiḥ al-Ghaib atau al-Tafsīr al-Kabīr. Fakhruddīn al-Rāzī merupakan seorang pemikir yang kuat dalam membela madzhabnya. Ia kerap mengkritik madzhab lain yang berbeda dan mengunggulkan pendapat dalam madzhabnya. Keilmuan Fakhruddīn al-Rāzī dalam bermacam-macam jenis ilmu sangat mumpuni. Dengan semangat yang menggebu-gebu dalam mempelajari banyak disiplin ilmu,

\footnotetext{
${ }^{46}$ Mun'im A. Sirry, Sejarah Fiqih Islam, 100.

47 Ibid., 105.

${ }^{48}$ Musāid Muslim Abdillāh Ali Ja'far, Atsar al-Tathawwur al-Fikrī, 200.
} 
Nalar Ideologis Fiqih dalam Tafsir al-Qur'an .....

Benny Afwadzi

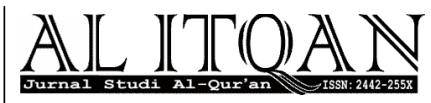

Fakhruddīn al-Rāzī melahirkan berbagai karya tulis dalam beberapa jenis ilmu, seperti ushuluddin, manāqib, kedokteran, dan bahkan astronomi. ${ }^{49}$ Beberapa kitab yang berhasil ditulisnya antara lain al-Tafsīr al-Kabīr, al-Mathālib al- 'Aliyah, Nihāyah al- 'Uqūl, al-Bayān dan al-Burhān fì al-Radd 'alā Ahl al-Zaighi wa al-Thughyān. ${ }^{50}$

Mafätiḥ al-Ghaib atau al-Tafsīr al-Kabīr merupakan representasi kitab tafsir yang sebenarnya, yang dimulai dengan penafsiran surat al-Fātiḥaḥ sampai surat al-Nās. Dalam kitabnya tersebut, Fakhruddīn al-Rāzī mampu menguraikan makna al-Qur'an hingga tiga puluh dua jilid. ${ }^{51}$ Kitab ini kaya dengan berbagai perspektif keilmuan, dari mulai pemikiran kalam, filsafat, ushul fiqih, fiqih, tasawuf, dan astronomi. Hampir semua disiplin keilmuan yang pernah digeluti oleh al-Rāzī dituliskan dalam kitab tafsirnya. Sampai-sampai muncul "sindiran" yang menyebut bahwa di dalamnya terdapat segala macam hal kecuali tafsir itu sendiri (fïhi kullu syā̄`illā al-tafsìr).

\section{Madzhab Ḥanbali}

Nama lengkap pendiri madzhab ini adalah Aḥmad bin Muḥammad bin Hanbal. Dia dilahirkan di Baghdad pada $164 \mathrm{H}$. dan meninggal pada tahun 241 di kota yang sama. Ia merupakan keturunan Arab asli dan nasabnya bertemu dengan Nabi Muhammad pada Nizār bin Ma`ād bin `Adnān. ${ }^{52}$ Madzhab Ḥanbali adalah madzhab fiqih yang bertipe fundamentalis, yang sangat keras terhadap suatu hukum. Ia lebih banyak mengadopsi hadits, bahkan hadits dhaif sekalipun, daripada memakai akal. Bagi Imam Aḥmad, hadits dhaif lebih layak dipakai untuk memperoleh kepastian hukum dibandingkan menggunakan akal.

Tercatat ada dua orang yang berpengaruh dalam pemikiran Imam Aḥmad, yaitu Hisyām bin Basyīr bin Khāzim, seorang imam ahli hadits pada eranya dari Baghdad dan Muḥammad bin Idrīs al-Syāfìi, pendiri madzhab Syafi'i. Namun, tokoh pertama lebih dominan dan sangat dihormati dalam kehidupannya. Bahkan, sampai-sampai Aḥmad bin Hanbal tidak berbicara tatkala gurunya itu datang serta tidak bertanya sesuatu apapun padanya selamanya. $^{53}$

\footnotetext{
49 Ibid., 200-201.

${ }^{50}$ Tājuddīn Abī Nashr Abd al-Wahhāb bin 'Alī bin Abd al-Kāfì al-Subkī, Thabaqāt al-Syāfi'iyyah al-Kubrā, (t.p.: Dār Ihyyā’ al-Kutub al-'Arabiyyah, t.t.), juz VIII, 87.

${ }^{51}$ Muhammad al-Rāzī Fakhruddīn bin Umar, al-Tafsīr al-Kabīr, (Beirut: Dār al-Fikr, 1981).

${ }^{52}$ Mun'im A. Sirry, Sejarah Fiqih Islam, 116.

${ }^{53}$ Musāid Muslim Abdillāh Ali Ja'far, Atsar al-Tathawwur al-Fikrī, 205-206.
} 
Madzhab Ḥanbalī menggunakan hadits lebih banyak dibandingkan dengan madzhab lainnya. Imam Aḥmad sendiri lebih dikenal sebagai ahli hadits dengan kitabnya yang bertitel Musnad Aḥmad, yang masuk jajaran kutub al-tis 'ah (sembilan kitab primer hadits). Pendiri madzhab ini, Aḥmad bin Hanbal mempunyai metode istinbath hukum sebagai berikut: alQur'an, sunnah (yang shahih dan dhaif yang tidak parah), konsensus sahabat, perkataan sahabat jika terjadi pertentangan dan tidak keluar dari pendapat mereka, qiyas, al-mashālih alMursalah, dan istish hāab. ${ }^{54}$

Di antara kitab yang bercorak madzhab Hanbalī antara lain Zād al-Maisìr fì Ilm alTafsīr karya Abū al-Faraj Jamāluddīn `Abdirraḥmān bin `Alī bin Muhammad al-Jauzī alQurasȳ̄ al-Baghdadī (508-597 H.) atau yang dikenal dengan nama Ibnu al-Jauzī. ${ }^{55}$ Secara nasab, ia bertemu dengan Abu Bakar al-Shiddīq yang menyebabkan ia mendapatkan nama nisbat al-Bakarī. Ibnu al-Jauzī merupakan ulama Ḥanābilah terpandang, yang telah mengarang berbagai buku dalam banyak disiplin ilmu, seperti tafsir, ulumul al-Qur'an, hadits, fiqih, ushul fiqih, ushuluddin, dan lain sebagainya. ${ }^{56}$ Beberapa karya yang telah ditulisnya antara lain al-Mughnī fì al-Tafsīr, Zād al-Maisīr fì Ilm al-Tafsìr, Minhāj al-Wushūl ilā Ilm alUshūl, Jāmi al-Masānid bi Alkhāsh al-Anānīd, al-Mujtabāa, al-Madzhab fì al-madzhab, dan al-Inshaffi masāil al-Khilāf. ${ }^{57}$

Kitab yang terdiri atas empat jilid ini bukanlah kitab tafsir ayat-ayat hukum saja melainkan tafsir atas semua ayat yang termaktub dalam al-Qur'an. Dalam menafsirkan alQur'an, Ibnu al-Jauzī memulai dengan menuturkan keutamaan dari surat tersebut, mencantumkan asbāb al-nuzūl atau waktu nuzulnya apabila ditemukan, hikmah yang terkandung di dalamnya, menyebutkan surat tersebut makkiyah atau madaniyah, dan kemudian baru menginjak pada tafsir ayatnya. ${ }^{58}$ Nuansa madzhab Hanbali cukup terasa dalam kitab tafsir ini. Ibnu al-Jauzi yang bermadzhab Hanbali lebih condong pada madzhab yang dianutnya, meskipun sebelumnya didahului oleh pendapat dalam madzhab-madzhab lainnya. Bahkan, terkadang dirinya hanya menyebutkan pendapat madzhab Hanbali saja

\footnotetext{
54 Ibid., 208.

55 Abū al-Faraj Jamāluddīn 'Abdirraḥmān bin 'Alī bin Muḥammad al-Jauzī al-Qurasȳ̄ al-Baghdadī, Zād alMaisīr fì Ilm al-Tafsīr, (Beirut: Dār Ibnu ḥazm, 2002).

${ }^{56}$ Musāid Muslim Abdillāh Ali Ja’far, Atsar al-Tathawwur al-Fikrī, 209.

57 Zāhīr al-Syāwīsy, "Tarjamah Ibnu al-Jauzī” dalam Abū al-Faraj Jamāluddīn 'Abdirraḥmān bin 'Alī bin Muḥammad al-Jauzī al-Qurasȳ̄ al-Baghdadī, Zād al-Maisīr fì Ilm al-Tafsīr, 23-25.

${ }^{58}$ Musāid Muslim Abdillāh Ali Ja’far, Atsar al-Tathawwur al-Fikrī, 211.
} 
Nalar Ideologis Fiqih dalam Tafsir al-Qur'an .....

Benny Afwadzi

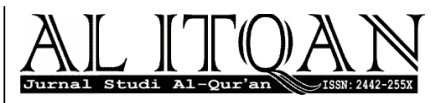

dalam keterangannya. Jika terdapat dua riwayat pendapat yang disandarkan pada Imam Ahmad terkait sebuah permasalahan, maka ia akan menyebutkan keduanya. ${ }^{59}$

\section{E. Nalar Ideologis dalam Tafsir Ayat-Ayat Hukum pada Periode Abbasiyah}

Tafsir al-Qur'an yang lahir pada periode pertengahan banyak didominasi oleh kepentingan-kepentingan politik, madzhab, atau ideologi keilmuan tertentu. Dengan adanya hal ini, maka al-Qur'an seringkali diposisikan sebagai legitimasi atas kepentingankepentingan tersebut. Sebelum memproduksi tafsir al-Qur'an, seseorang telah terselimuti dulu dengan ideologi-ideologi yang dianutnya. Kemudian, ideologi itulah yang nantinya berperan besar dalam corak dan bentuk tafsir yang dihasilkan. ${ }^{60}$

Jika dilihat secara umum, tradisi penafsiran yang muncul pada era afirmatif (pertengahan) terkontaminasi oleh fanatisme madzhab dan kepentingan politik tertentu. Akibatnya, tafsir yang dihasilkan pun terlihat sangat ideologis, subjektif, dan juga tendensius. Dalam bahasa Nasr Hamid Abu Zayd, salah seorang intelektual kontemporer, tradisi tafsir pada era pertengahan disebut sebagai bentuk pembacaan al-Qur'an yang bersifat ideologistendensius (qirā'ah talwin̄yyah mughridhah). ${ }^{61}$

Secara lebih detail, struktur epistemologi tafsir al-Qur'an yang ada dalam era afirmatif sebagaimana diungkapkan Abdul Mustaqim adalah sebagai berikut: 1) Sumber penafsiran didominasi oleh akal (ijtihad) daripada al-Qur'an atau hadits itu sendiri. Dalam konteks ini, para mufassir menggunakan teori-teori keilmuan yang ditekuninya untuk menafsirkan alQur'an, seperti filsafat, tasawuf, kalam, fiqih, dan lain sebagainya. 2) Metode penafsiran yang diusung adalah bi al-ra'yi (menggunakan akal), deduktif-taḥlīli, memakai analisis kebahasaan, dan mencocok-cocokkan dengan teori-teori dari suatu disiplin keilmuan atau juga madzhab si mufassir. 3) Validitas penafsiran yang ada adalah koherensi, yakni kesesuaian antara hasil penafsiran dengan kepentingan penguasa, madzhab (aliran), dan ilmu yang ditekuni oleh sang mufassir. 4) Karakteristik penafsiran bersifat ideologis, sektarian, atomistic repetitive, pemaksaan gagasan non-Qur`ani, ada kecenderungan truth claim, dan subjektif. Sedangkan tujuan penafsiran yang dilakukan adalah untuk kepentingan kelompok,

\footnotetext{
59 Ibid., 209.

${ }^{60}$ Abdul Mustaqim, Pergeseran Epistemologi Tafsir, 59.

61 Ibid., 70-71.
} 
mendukung kekuasaan, madzhab, atau ilmu yang digeluti mufassir. ${ }^{62}$

Pada masa dinasti Abbasiyah sebagai salah satu bagian abad pertengahan yang merupakan masa kemajuan pemikiran, bermunculan banyak mufassir, baik yang menafsirkan seluruh ayat al-Qur'an atau hanya lebih menspesifikasikan pada ayat-ayat hukum saja. Mereka memberikan corak fiqih (laun al-fiqhi) pada produk tafsir yang dihasilkannya. Keilmuan fiqih yang digeluti oleh mereka dipergunakan untuk mendekati ayat-ayat al-Qur'an, menyibak makna-makna al-Qur'an, dan menggali hukum yang terkandung di dalamnya.

Meskipun demikian, sebagaimana kecenderungan yang timbul secara umum, tafsir ayat-ayat hukum yang dilakukan pada masa Abbasiyah berfungsi sebagai pembela madzhab yang dianutnya, sehingga nalar yang dipergunakan adalah nalar ideologi. Ideologi mempunyai andil penting dalam menentukan hasil akhir sebuah penafsiran ayat-ayat hukum. Dengan kata lain, madzhab yang dianut oleh sang mufassir akan mengkonstruksi cara berpikir dan hasil penafsiran ayat-ayat al-Qur'an. Terkadang pula, dengan semangat membela ideologi madzhab tersebut juga, orang-orang yang berbeda pendapat dengan madzhabnya pun diserang dengan tafsir al-Qur'an.

Untuk menjelaskan nalar ideologis dalam tafsir ayat hukum di atas, berikut beberapa contoh tafsir ayat-ayat al-Qur'an yang menitikberatkan pada diskusi seputar dilālah yang terkandung dalam redaksi al-Qur'an, yakni khās dan ‘ām, amr dan nahy, serta lafadz musytarak. Nantinya akan terlihat bagaimana ideologi mengambil peranan penting dalam sebuah produk penafsiran. Adapun bentuk penafsiran al-Qur'an sendiri diambil dari kitabkitab tafsir dari masing-masing madzhab sebagaimana dipaparkan dalam pembahasan sebelumnya. ${ }^{63}$

\section{Khās dan ' $\bar{A} m$}

Khās merupakan redaksi yang diletakkan pada satu arti tertentu dan menyendiri. Para sarjana hukum Islam sepakat bahwa dilālah yang terkadung di dalamnya bersifat qath $i$. Namun mereka berbeda pendapat terkait dua hal, yaitu pertama, apakah redaksi khās yang dipandang qath $i$ al-dilālah-nya itu sudah jelas dengan sendirinya, sehingga tidak memerlukan penjelasan lain atau perubahan makna ataukah sekalipun sudah qath $i$ tetapi

\footnotetext{
62 Ibid., 72.

${ }^{63}$ Pelacakan dalam tulisan ini dibantu oleh kajian yang dilakukan oleh Musāid mengenai dampak perkembangan pemikiran terhadap tafsir pada periode dinasti Abbasiyah. Lihat Atsar al-Tathawwur al-Fikrī.
} 
Nalar Ideologis Fiqih dalam Tafsir al-Qur'an .....

Benny Afwadzi

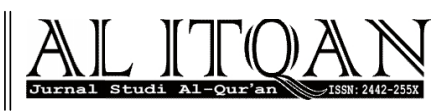

kemungkinan mempunyai perubahan atau penjelasan lain. ${ }^{64}$ Kedua, mengenai posisi tambahan (ziyādah) pada redaksi khās, apakah merupakan sebuah bentuk penghapusan (naskh) atau tidak? ${ }^{65}$

Menurut Hanafiyah, tambahan tersebut merupakan bentuk naskh, sehingga tidak diperbolehkan untuk menerima tambahan dari khabar wāhid. ${ }^{66}$ Sementara mayoritas sarjana (Syafî̀iyah, Mālikiyah, dan Ḥanabilah) berpendapat bahwa tambahan itu bukan naskh, sehingga diperbolehkan memberikan tambahan pada hukum yang terkandung pada ayat tersebut. Masing-masing madzhab mengukuhkan pola pikir tersebut dalam kitab tafsirnya. Salah satunya adalah dalam tafsir ayat berikut:

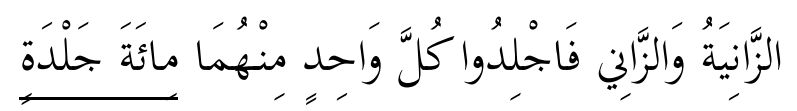

"Perempuan yang berzina dan laki-laki yang berzina, Maka deralah tiap-tiap seorang dari keduanya seratus dali dera” QS. al-Nūr[24]: 2.

Abū Bakar al-Jashshāsh yang bermadzhab Ḥanafi dalam Ahkām al-Qur`ān berpendapat bahwa hukuman yang diberikan hanya berupa cambuk, tanpa disertai dengan pengasingan, sebab ia tidak menerima penambahan pada redaksi yang sudah $k h \bar{a} s$. Meskipun ada hadits dari 'Ubādah bin al-Shāmid yang menyatakan adanya tambahan hukuman bagi pezina yang belum menikah dengan hukuman pengasingan (taghrīb), tetapi haditsnya ahâad. Dengan demikian, tidak dapat diposisikan sebagai ziyādah, karena perbedaan status wurūd. ${ }^{67}$ Pendiri madzhab ini, Imam Abū Ḥanīfah juga berpendapat bahwa hukumannya hanya dijilid dengan tanpa diasingkan.

Pendapat yang bercorak Hanafiyah seperti itu lantas disanggah oleh Fakhruddīn alRāzī yang bermadzhab Syāfi’i dalam al-Tafsīr al-Kabīr dengan menandaskan adanya tambahan hukuman pengasingan. Menurutnya, berita adanya pengasingan yang berasal dari hadits aḥād tidak menghilangkan kewajiban hukuman cambuk sebagaimana ditunjukkan oleh redaksi al-Qur'an. Kolaborasi antara hukuman cambuk dengan pengasingan juga menjadi

\footnotetext{
${ }^{64}$ Rachmat Syafe'i, Ilmu Ushul Fiqih (Bandung: Pustaka Setia, 2010), 189.

${ }^{65}$ Musāid Muslim Abdillāh Ali Ja'far, Atsar al-Tathawwur al-Fikrī, 232.

${ }^{66}$ Hal ini disebabkan karena mekanisme naskh (penghapusan) harus dilakukan oleh dua dalil yang sama tingkatannya dari segi wurūd.

${ }^{67}$ Lihat logika berpikir ini dalam Abū Bakar Aḥmad bin Alī al-Rāzi al-Jashshāsh, Aḥkām al-Qur'ān, jilid 3, 4149. Musāid Muslim Abdillāh Ali Ja'far, Atsar al-Tathawwur al-Fikrī, 234.
} 


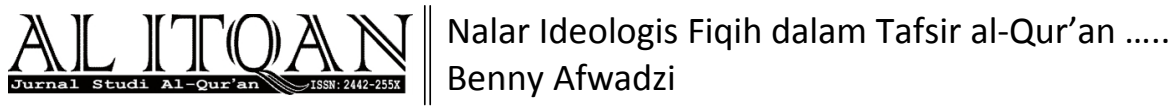

pendapat Imam al-Syāfi i, sang pendiri madzhab. ${ }^{68}$ Dalam pendapat lainnya, Kalangan Mālikiyah dan Hanabilah juga berpendapat demikian. Hanya saja, Mālikiyah berpandangan bahwa hukuman pengasingan tidak diberlakukan pada perempuan. ${ }^{69}$

Sementara ‘amm adalah satu redaksi yang dari satu segi menunjukkan pada dua aspek atau lebih. Formula yang dipakai untuk menunjukkan redaksi ‘̄m beragam, yaitu isim syarath, isim maushūl, kull, alif làm, dan lain sebagainya. Para ulama sepakat mengenai keqath $i$-an redaksi `àm yang menujukkan bahwa redaksi itu benar-benar umum. Mereka juga sepakat bahwa redaksi 'àm yang disertai qarīnah, yang dimaksudkan itu khusus, maka mempunyai dilālah yang khusus pula. ${ }^{70}$ Namun, mereka berbeda pandangan terkait lafazh ‘̄m muthlaq, yang tidak disertai dengan qarīnah yang menolak kemungkinan adanya takhshīsh atau berlaku umum yang mencakup satuan-satuannya. ${ }^{71}$

Ḥanafiyah berpendapat bahwa dilālah yang terkandung dalam redaksi ‘àm tersebut berstatus qath $\nearrow_{\imath}$, sebagaimana dilālah redaksi khāsh pada maknanya. Akan tetapi, mayoritas (jumhur) ulama mempunyai pandangan berbeda. Mereka memandang bahwa dilālah-nya zhannī, sebagaimana khabar wăḥid dan qiyās. Menurut mayoritas ulama, redaksi ‘àm tidak bisa berstatus qath $i$, kecuali jika ada qarinah. Implikasi pendapat ini dapat dilihat dalam ayat di bawah ini:

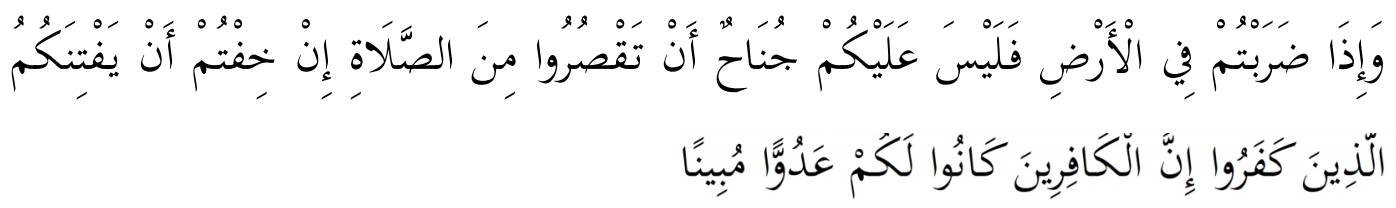

"Dan apabila kamu bepergian di muka bumi, maka tidaklah mengapa kamu menqashar sembahyang(mu), jika kamu takut diserang orang-orang kafir. Sesungguhnya orang-orang kafir itu adalah musuh yang nyata bagimu” QS. alNisā [4]: 101 .

Abū Bakar al-Jashshāsh dari kalangan Ḥanafiyah menyatakan bahwa dispensasi (keringanan) berupa qashar yang dimaksud dalam ayat tersebut diberikan pada musafir dalam setiap keadaan apapun, baik untuk keperluan bisnis maupun kegiatan-kegiatan lain

\footnotetext{
${ }^{68}$ Muḥammad al-Rāzī Fakhruddīn bin Umar, al-Tafsīr al-Kabīr, jilid 23, 138.

${ }^{69}$ Musāid Muslim Abdillāh Ali Ja’far, Atsar al-Tathawwur al-Fikrī, 235.

${ }^{70}$ Rachmat Syafe'i, Ilmu Ushul Fiqih, 194.

${ }^{71}$ Musāid Muslim Abdillāh Ali Ja'far, Atsar al-Tathawwur al-Fikrī, 237.
} 
sebagainya dengan jangka waktu tiga hari tiga malam. ${ }^{72}$ Sementara itu, bagi Ibnu al-Jauzī dari kalangan Ḥanābilah, dispensasi itu hanya dapat diberikan pada bepergian yang diperbolehkan (mubah) saja. Untuk tujuan kemaksiatan, tidak diperbolehkan untuk meng-qashar shalat. Pendapat seperti ini juga merupakan pendapat Imam Mālik dan Imam al-Syāfi i. Namun, disebutkan pula oleh Ibnu al-Jauzīe Abū ḥan̄fah berpandangan bahwa diperbolehkan untuk melakukan qashar meskipun dalam tujuan maksiat. ${ }^{73}$

Perbedaan yang timbul di antara dua pandangan di atas diakibatkan oleh adanya dua perspektif yang berbeda. Jumhur ulama (Hanābilah, Mālikiyah dan Syafì iyah) memahami bahwa diperkenankan adanya pen-takhsìsh-an redaksi ‘àm dengan khabar wāhid atau qiyās dalam ayat ke 101 dari surat al-Nisā’. Takhshīsh berupa pengecualian dalam kemaksiatan merupakan qiyās yang diberlakukan pada redaksi ‘àm dalam ayat tersebut. Dengan pola pikir ini, maka dispensasi qashar hanya diberlakukan pada musafir selain dalam rangka kemaksiatan. Sedangkan ulama Hanafiyah memahami bahwa tidak adanya takhsissh dengan dalil yang zhannī, seperti khabar wāhnid atau qiyās. Pen-takhshīsh-an pada ayat al-Qur'an hanya dapat dilakukan dengan dengan dalil yang qath $i$ pula, yakni al-Qur’an.

\section{Amr dan Nahy}

Amr (perintah) adalah perkataan yang menunjukkan keharusan untuk melakukan sesuatu yang diperintah. Pada ahli fiqih berbeda pandangan tentang amr yang tidak disertai qaīnah. Menurut Syāfi iyah, kata tersebut menuntut adanya pengulangan tanpa adanya qaīnah. Sementara dari kubu Hanafiyah menyatakan bahwa hal itu tidak menghendaki adanya pengulangan. Mālikiyah sepakat dengan Syāfi iyyah, sedangkan Hanābilah setuju dengan Hanafiyah. Implikasi pandangan tersebut dapat dijelaskan dengan tafsir ayat berikut:

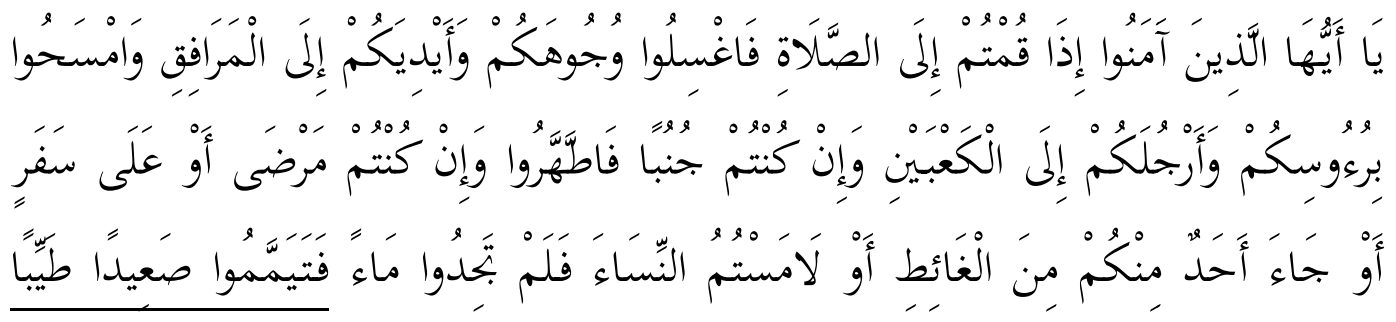

\footnotetext{
${ }^{72}$ Abū Bakar Aḥmad bin Alī al-Rāzī al-Jashshāsh, Aḥkām al-Qur’ān, jilid 3, 234.

${ }^{73}$ Abū al-Faraj Jamāluddīn 'Abdirraḥmān bin 'Alī bin Muḥammad al-Jauzī al-Qurasyi al-Baghdadī, Zād alMaisìr fì Ilm al-Tafsīr, 319.
} 


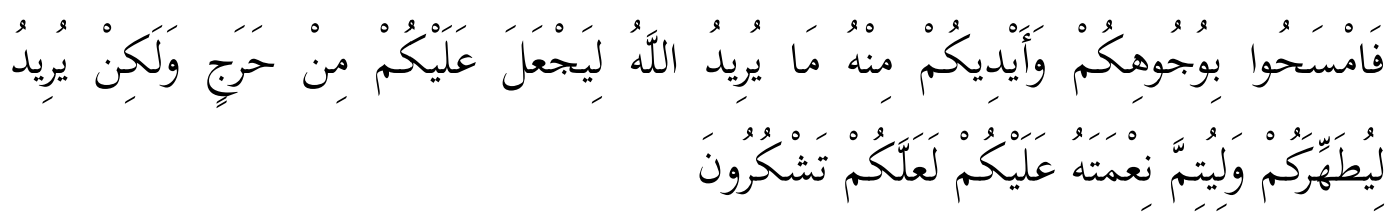

"Maka bertayamumlah kamu dengan tanah yang baik (suci)” QS. alMāidah[5]:6.

Dalam kacamata al-Jashshāsh, tayamum hanya dilakukan sekali saja pada shalat yang dikehendaki sampai berhasil menemukan air. Hal ini berarti bahwa seseorang diperbolehkan bertayamum satu kali untuk melaksanakan shalat berkali-kali. Dalam kitab tafsirnya, ia menyalahkan pendapat orang-orang yang berpandangan bahwa harus memperbaharui tayamum untuk shalat. Argumentasi yang diajukan adalah bahwa kata "idzā qumtum" dalam redaksi awal dalam ayat tersebut secara bahasa tidak menghendaki adanya pengulangan. ${ }^{74}$

Di sisi lain, Fakhruddīn al-Rāzī berpendapat bahwa perbaharuan tayamum hanya berlaku untuk satu shalat fardhu saja. Dalam konteks ini, ia mengutip argumentasi yang dibangun oleh Imam al-Syāfi '̄. Menurut al-Syāfì ${ }^{1}$, sebagaimana dikutip al-Rāzī, istidlāl yang diambil adalah secara lahiriahnya ayat tersebut menghendaki perintah untuk melakukan wudhu setiap hendak melaksanakan shalat jika terdapat air. Namun, apabila tidak menemukan air, maka ia harus diganti dengan tayamum yang tentunya meninggalkan aktivitas bersuci dalam wudhu sesuai dengan perilaku Nabi. Dengan demikian, kandungan hukum yang tersisa dalam ayat tayamum tersebut adalah lahiriahnya ayat saja, yakni bersuci setiap hendak melaksanakan shalat. $^{75}$

Sementara itu, nahy (larangan) merupakan perkataan yang mempunyai tujuan untuk meninggalkan suatu perbuatan. Pro-kontra yang timbul dari tema ini berkisar pada fasād yang dimunculkan oleh larangan. Apakah setiap larangan mempunyai implikasi batalnya sebuah perbuatan ataukah tidak. Perdebatan seputar hal ini dapat disimak dalam berbagai interpretasi atas ayat berikut:

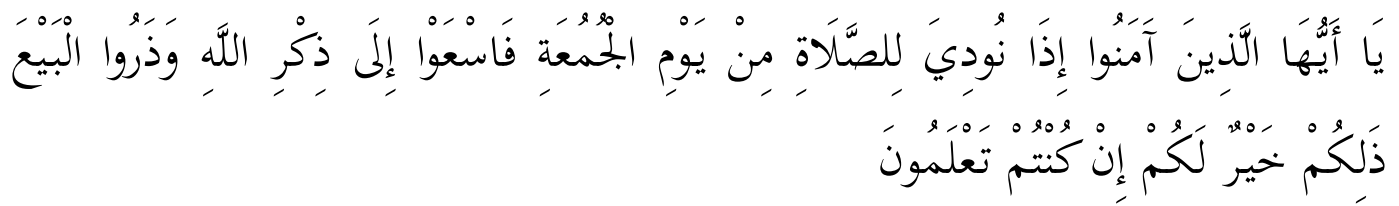

\footnotetext{
${ }^{74}$ Abū Bakar Aḥmad bin Alī al-Rāzī al-Jashshāsh, Aḥkām al-Qur'ān, jilid 4, 22.

${ }^{75}$ Sebelumnya, al-Rāzī menerangkan bahwa al-Syāfi'i melarang melakukan tayamum untuk dua shalat fardhu, tetapi hal itu tidak terjadi pada wudhu (maknanya, wudhu boleh digunakan untuk dua shalat fardhu). Muhammad al-Rāzī Fakhruddīn bin Umar, al-Tafsīr al-Kabīr, jilid 11, 178.
} 
Nalar Ideologis Fiqih dalam Tafsir al-Qur'an .....

Benny Afwadzi

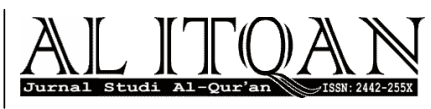

"Hai orang-orang beriman, apabila diseru untuk menunaikan shalat Jum 'at, maka bersegeralah kamu kepada mengingat Allah dan tinggalkanlah jual beli. yang demikian itu lebih baik bagimu jika kamu mengetahui." QS. alJum`ah[62]:9.

Abū Bakar al-Jashshāsh dalam Aḥkām al-Qur'ān menganggap jual beli yang dilakukan pada saat menginjak waktu shalat jum at tetap sah. Ia berargumentasi dengan Q.S. al-Nisā' [4]: $29^{76}$ yang menyatakan bahwa jual beli sah apabila terjadi saling ridha antara kedua belah pihak. Adapun larangan dalam surat al-Jum 'ah di atas tidak berhubungan dengan subtansi akad, tetapi lebih pada menyibukkan diri ketika shalat. Dari logika tersebut, larangan berupa jual beli saat shalat Jum`at tidak meruntuhkan sahnya sebuah perbuatan shalat jum `at itu sendiri, meskipun perbuatan tersebut masuk kategori nahy. ${ }^{77}$

Sementara Ibnu al-Jauzī dari golongan Ḥanābilah menyatakan bahwa tidak diperbolehkan melakukan jual beli pada saat adzan Jum 'at. Lebih jauhnya, jual beli yang dilakukan pada waktu itu menjadi batal bagi orang yang memiliki kewajiban menunaikan ibadah Jum `at. Dalam penuturan Ibnu al-Jauzī, perkataan tersebut diklaim juga merupakan pendapat imam Mālik, yang berlainan dengan pendapat kebanyakan ulama seperti Abū Hanīfah, al-Syāfìi, dan selainnya. ${ }^{78}$

\section{Musytarak}

Redaksi musytarak merupakan satu lafazh yang mempunyai dua makna. Dengan arti lain, katanya memang tunggal, tetapi makna yang ditimbulkannya jamak. Redaksi seperti ini banyak terdapat dalam al-Qur'an, yang perbedaan pendapat yang ditimbulkannya juga sangat beragam. $^{79}$

Di antara contoh lafazh musytarak ini adalah huruf wawu, yang memang mempunyai dua makna, yaitu urut atau tartib dan terpisah (tidak urut). Salah satu ayat al-Qur'an yang menimbulkan perdebatan yang berasal dari huruf wawu yang musytarak adalah al-Māidah ayat 6 . Berikut penafsiran ayat tersebut berdasarkan perpektif madzhab.

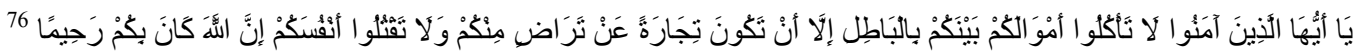

${ }^{77}$ Abū Bakar Aḥmad bin Alī al-Rāzi al-Jashshāsh, Aḥkām al-Qur'ān, jilid 5, 341.

${ }^{78}$ Abū al-Faraj Jamāluddīn 'Abdirraḥmān bin 'Alī bin Muḥammad al-Jauzī al-Qurasȳ̄ al-Baghdadī, Zād alMaisīr fì 'Ilm al-Tafsīr, 1436.

${ }^{79}$ Musāid Muslim Abdillāh Ali Ja’far, Atsar al-Tathawwur al-Fikrī, 252.
} 


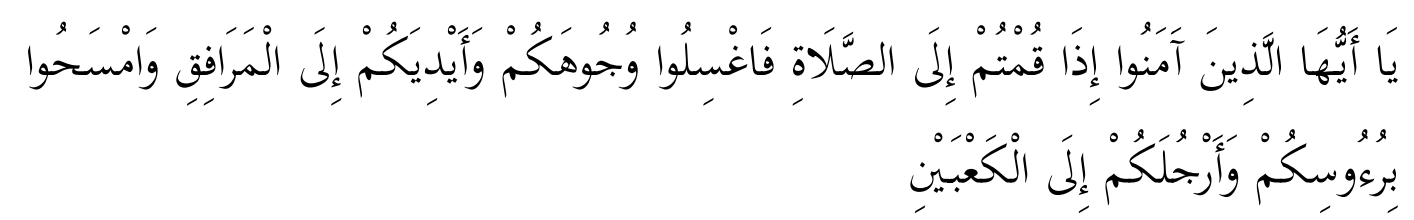

"Hai orang-orang yang beriman, apabila kamu hendak mengerjakan shalat, Maka basuhlah mukamu dan tanganmu sampai dengan siku, dan sapulah kepalamu dan (basuh) kakimu sampai dengan kedua mata kaki"

Menurut al-Jashshāsh, ayat di atas membatalkan pendapat orang yang mengharuskan adanya tartib dalam wudhu. Seseorang yang berwudhu, baginya, diperbolehkan mendahulukan satu dengan yang lainnya sesuai apa yang dikehendaki. Hal yang menarik adalah ternyata al-Jashshāsh mengkritik secara keras pendapat Imam al-Syāfìi yang mengharuskan adanya sifat berurutan dengan mengkategorikan pendapat tersebut telah keluar dari konsensus (ijma') para ulama salaf dan fuqaha`. Bagi Abū Bakar al-Jashshāsh, huruf wawu tidak mewajibkan tartib sesuai dengan pendapat ahli bahasa. ${ }^{80}$

Sementara Ibnu al-'Arabī lebih cenderung memaknai tartib dalam ayat di atas. Huruf $f a{ }^{\prime}$ dalam kata faghsilū bermakna ta' $q \bar{\imath} b$ sehingga menghendaki adanya pertalian antara satu aktivitas dengan aktivitas lainnya. Baginya, pendapat yang shahih adalah mendahulukan apa yang didahulukan oleh Allah. Ia menegaskan pandangannya dengan salah satu hadits Nabi ketika melakukan ibadah haji. Dikisahkan bahwa saat Nabi telah sampai di bukit Shafa, beliau lalu bersabda "Kita memulai dengan apa yang telah didahulukan oleh Allah, dan permulaan (sa `i) dari bukit Shafa merupakan sebuah kewajiban.” Selain itu pula, Nabi Muhammad dalam seluruh umurnya selalu melakukan wudhu secara urut sebagaimana urutan yang tertera dalam ayat al-Qur'an. Perilaku Nabi tersebut merupakan bayān mujmal terhadap ayat al-Qur'an, dan bayān mujmal wājib dihukumi wajib. ${ }^{81}$ Pendapat seperti yang dipaparkan Ibnu al-Arabī ini adalah pendapat sekelompok ulama Mālikiyah yang berlainan dengan pandangan Mālikiyah pada umumnya. ${ }^{82}$

Fakhruddīn al-Rāzi dari kalangan Syāfi 'iyyah juga memiliki pendapat yang sama seperti Ibnu al-Arabi. Ia mengutip pendapat Imam al-Syāfi i i, pendiri madzhabnya mengenai perilaku tartib yang menjadi syarat sahnya wudhu yang dilengkapi dengan berbagai argumentasi yang diusung oleh al-Syāfi ’i. Di lain pendapat, Imam Mālik dan Abū Ḥanīfah

\footnotetext{
${ }^{80}$ Abū Bakar Aḥmad bin Alī al-Rāzi al-Jashshāsh, Ahkāmm al-Qur'ān, jilid 3, 368.

${ }^{81}$ Abū Bakar Muḥammad bin 'Abdillāh Ibn al-'Arabi, Ahkām al-Qur'ān, jilid 2, 52.

${ }^{82}$ Musāid Muslim Abdillāh Ali Ja’far, Atsar al-Tathawwur al-Fikri, 254.
} 
Nalar Ideologis Fiqih dalam Tafsir al-Qur'an .....

Benny Afwadzi

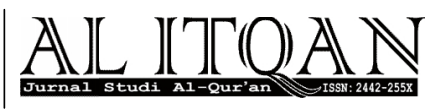

mempunyai pendapat yang berbeda dengan tidak mencantumkan tartib dalam syarat sah wudhu. ${ }^{83}$

\section{F. Penutup}

Dari pemaparan di atas, dapat disimpulkan bahwa madzhab yang dianut oleh seorang mufassir sangat mempengaruhi produk penafsirannya. Atau dengan maksud lain, ideologi seorang mufasisr berimplikasi kuat pada tafsir mereka terhadap ayat-ayat hukum dalam alQur'an. Mereka dengan gigih membela pendapat dan pola pikir dalam madzhab yang dianutnya. Seseorang yang bermadzhab Ḥanafi secara umum akan mendasarkan penafsirannya pada madzhab yang dianutnya tersebut, bagitu pula madzhab Māliki, Syāfi i, ataupun juga Hanbali. Akibatnya, tafsir ayat-ayat hukum yang muncul pun berwarna sesuai dengan warna madzhab si mufassir. Proses seperti inilah yang disebutkan sebagai nalar ideologis yang banyak terjadi pada periode afirmatif (pertengahan), yang dalam tulisan ini difokuskan pada dinasti Abbasiyah dengan kemajuan ilmu fiqih masing-masing madzhab.

\section{DAFTAR PUSTAKA}

Ahmed, Akbar S. Citra Muslim: Tinjauan Sejarah dan Sosiologi, erj. Nunding Ram dan Ramli Yakub. Jakarta: Erlangga, 1992.

al- 'Arabi, Abū Bakar Muḥammad bin `Abdillāh Ibn Aḥkām al-Qur 'ān. Beirut: Dār Kutub alIlmiyyah, 2003.

al-Baghdadi, Abū al-Faraj Jamāluddīn `Abdirraḥmān bin `Ali bin Muḥammad al-Jauzi alQurasyi. Zād al-Maisìr fì Ilm al-Tafsìr. Beirut: Dār Ibnu Hazm, 2002.

Goldziher, Ignaz. Madzhab Tafsir dari Klasik Hingga Modern, terj. M. Alaika Salamullah dkk. Yogyakarta: elSAQ Press, 2006.

al-Ḥanafi, Muḥyiddīn Abī Muḥammad Abd al-Qādīr al-Qurasyi. al-Jawāhir al-Mudhiyyah fì Thabaqāt al-Hanafiyyah, juz I. Saudi Arabia: Hijr li al-Tibā’ah wa al-Nasyr wa alTauzi`wa al-I'lān, 1993.

Hitti, Philip K. Hisory of The Arab, terj. Cecep Lukman Yasin dan Dedi Slamet Riyadi. Jakarta: Serambi Ilmu Semesta, 2010.

\footnotetext{
${ }^{83}$ Muhammad al-Rāzi Fakhruddīn bin Umar, al-Tafsīr al-Kab̄̄r, jilid 11, 152-153.
} 
Ja`far, Musāid Muslim Abdillāh Ali. Atsar al-Tathawwur al-Fikri fì al-Tafsīr fì al-Ashr alAbbāsi. Beirut: Muassasah al-Risālah, 1984.

al-Jashshāsh, Abū Bakar Aḥmad bin Ali al-Rāzi. Aḥkām al-Qur 'ān. Beirut: Dār al-Iḥyā’ alTurats al-'Arabi, 1992.

Makhlūf, Muḥammad bin Muḥammad bin 'Umar bin Qāsim. Syajarah al-Nūr al-Zakiyyah fì Tabaqāt al-Mālikiyyah, juz I. Beirut: Dār Kutub al-Ilmiyyah, 2003.

Mustaqim, Abdul. Epistemologi Tafsir Kontemporer. Yogyakarta: LkiS, 2010. , Pergeseran Epistemologi Tafsir. Yogyakarta: Pustaka Pelajar, 2008.

Pamungkas, Imam dan Maman Surahman. Fiqih 4 Madzhab. Jakarta: al-Makmur, 2015.

al-Rāzi, Muhạmmad Fakhruddīn bin Umar. al-Tafsīr al-Kabīr. Beirut: Dār al-Fikr, 1981.

Sirry, Mun `im A. Sejarah Fiqih Islam: Sebuah Pengantar. Surabaya: Risalah Gusti, 1995.

al-Subki, Tājuddīn Abī Nasr Abd al-Wahhāb bin 'Ali bin Abd al-Kāfi. Thabaqāt alSyāfi ‘yyah al-Kubrā, juz VIII. t.p.: Dār Ihyā̄' al-Kutub al- 'Arabiyyah, t.t.

Syafe 'i, Rachmat. Ilmu Ushul Fiqih. Bandung: Pustaka Setia, 2010.

Watt, W. Montgomery. Kejayaan Islam: Kajian Kritis dari Tokoh Orientalis, terj. Hartono Hadikusumo. Yogyakarta: Tiara Wacana, 1990.

Yatim, Badri. Sejarah Peradaban Islam. Jakarta: Raja Grafindo Persada, 1995. 